\title{
DRUŠTVENO ODGOVORNO POSLOVANJE I KOMUNICIRANJE VOLONTERA U REALNOM I DIGITALNOM MEDUNARODNOM OKRUŽENJU
}

Važnost društveno odgovornog poslovanja predstavlja izazov u lokalnom i međunarodnom okruženju. U radu je opisan primjer umrežavanja studenata i volontera u okviru međunarodne razmjene stipendista McNair TRIO programa iz SAD-a i studenata volontera iz Varaždina. Ciljevi međunarodne suradnje studenata iz Varaždina, Chicaga, Orlanda i Pittsburgha su poticanje profesionalnih i društvenih kompetencija komuniciranja u međunarodnom okruženju te podizanje svijesti o potrebama pojedinaca, pripadnika socijalno osjetljivih skupina kroz projekte volontiranja. Program suradnje sadrži komponentu društveno korisnog učenja, volontiranja, interkulturnog učenja i znanstveno-stručnu komponentu. Studenti se umrežavanju u međunarodne istraživačke timove i pripremaju projekte vezane uz uključivanje socijalno osjetljivih skupina (studenti s invaliditetom, nižeg socioekonomskog statusa, pripadnici nacionalnih manjina ...) u proces visokog obrazovanja. Komunikacija se odvija kontaktno i uz uporabu digitalnih tehnologija. Evaluacija kvalitete provedenih projekta napravljena je temeljem kvantitativnih i kvalitativnih pokazatelja, prikupljene pozitivne povratne informacije. Stečena znanja i kompetencije mogu podići konkurentnost studenata prilikom budućeg zapošljavanja.

Ključne riječi: digitalni marketing; online trgovanje; SEM; PPC; SEO; sjeverna Hrvatska. 
VIOLETA VIDAČEK HAINŠ: Društveno odgovorno poslovanje i komuniciranje volontera...

\section{UVOD}

\subsection{Društveno odgovorno poslovanje i društveno korisno učenje}

Društveno odgovorno poslovanje je „odgovornost poduzeća za utjecaje na društvo " ${ }^{11}$ odnosno predanost poboljšanju dobrobiti zajednice kroz diskretne poslovne prakse i pružanje korporativnih resursa. ${ }^{2} U$ Republici Hrvatskoj evidentno je da $77 \%$ najuspješnijih poduzeća u vizijama i misijama ima spomenuto društveno odgovorno poslovanje. ${ }^{3}$ Autori navode da hrvatska poduzeća pojedinačno uključuju društveno odgovorno poslovanje, ali ne postoji sustavna strategija. Društvena odgovornost poduzeća je koncept prema kojem kompanije na dobrovoljnoj osnovi integriraju društvene i ekološke ciljeve i odnose s dionicima u vlastite poslovne procese. ${ }^{5}$

Institucije visokog obrazovanja imaju osim obrazovne i znanstvene uloge i ulogu služenja društvenoj zajednici. Obrazovni sustav prati potrebe sektora rada i studente priprema za društveno odgovorno poslovanje. Tako se na visokim učilištima uvodi društveno korisno učenje (engl. service learning) kao nastavna metoda kojom studenti „strukturirano znanje i vještine stečene na akademskom kolegiju primjenjuju na razvoj projekta kojim se rješava neki konkretan društveni problem, s ciljem obogaćivanja procesa usvajanja znanja kroz kritičko promišljanje o složenim uzrocima društvenih problema i međusobnu suradnju na zajedničkom projektu. ${ }^{6}$ Terminom učenje zalaganjem u zajednici autori opisuju model učenja koji potiče svrhovito i aktivno sudjelovanje studenata u lokalnoj zajednici

1 European Community of Consumer Cooperative - Euro Coop (2012). EC Communication - A renewed EU strategy 2011-2014 for Corporate Social Responsibility https://www.eurocoop.coop/news/39-ec-communication-a-renewed-eu-strategy-2011-2014-for-corporate-social-responsibility.ty.html (1. 11. 2020.)

2 Philip KOTLER, Nancy LEE, Društveno odgovorno poslovanje, suvremena teorija i najbolja praksa, M.E.P., Zagreb, 2009. str. 14.

3 Maja QUIEN, „Društveno odgovorno poslovanje kao konkurentna prednost: analiza ciljeva najuspješnijih tvrtki u Hrvatskoj", Učenje za poduzetništvo, 2, 1, 2012., 303-307.

4 Ivona VRDOLJAK RAGUŽ, Kate HAZDOVAC "Društveno odgovorno poslovanje i hrvatska gospodarska praksa", Oeconomica Jadertina, 4, 1, 2014., 40-58.

5 European Commission/ Europska komisija (2011). COM/2011/0681 - Communication from the Commission to the European Parliament, the Council, the European Economic and Social Committee and the Committee OF THE Regions. A Renewed EU Strategy 2011-14 for Corporate Social Responsibility Document 52011DC0681 https://eur-lex.europa.eu/legal-content/EN/ TXT/? uri=CELEX:5011DC0681 (12. 02. 2021.)

6 Nives MIKELIĆ PRERADOVIĆ, Učenjem do društva znanja: Teorija i praksa društveno korisnog učenja, Zavod za informacijske studije, Filozofski fakultet Sveučilišta u Zagrebu. Zagreb, 2009. 
po uzoru na društveno korisno učenje (engl. service learning).? Društveno korisno učenje može biti sastavni dio obaveznog ili izbornog predmeta te može povezivati ishode učenja dva ili više predmeta na preddiplomskom ili diplomskom studiju. Ciljevi društveno korisnog učenja predstavljaju sastavni dio ciljeva studenata u smislu stjecanja kompetencija za buduće tržište rada, zatim samih visokoškolskih ustanova u smislu pripreme studenata za buduće tržište rada i vanjskog partnera iz okruženja lokalne zajednice s ciljem provedbe društveno odgovornog poslovanja. Informiranje i edukacija studenata tijekom društveno korisnog učenja odvija se u realnom i virtualnom okruženju. Uporaba suvremenih digitalnih tehnologija omogućava razmjenu informacija na daljinu. Digitalne tehnologije i uporaba društvenih mreža omogućavaju pronalaženje, pohranu, razmjenu i upravljanje informacijama u procesu obrazovanja. Tako je na primjer u sklopu projekta Commenius Intercultural Lerning ${ }^{10}$ koji je provodila Varaždinska županija, a u kojem su sudjelovali studenti volonteri Centra za volontiranje i humanitarni rad Fakulteta (CZVHR FOI), postignut zajednički cilj podizanja komunikacijskih kompetencija učenja engleskog jezika kod učenika osnovne škole. Dio korisnika projekta bili su učenici, pripadnici romske nacionalne manjine. Studenti volonteri tijekom projekta pripremali su i provodili komunikacijske vježbe te ujedno i sami razvijali znanja i metodološke kompetencije komuniciranja u nacionalnom i međunarodnom okruženju.

Bojana ĆULUM, Jasminka LEDIĆ, „Učenje zalaganjem u zajednici - integracija visokoškolske nastave i zajednice u procesu obrazovanja društveno odgovornih i aktivnih građana", Revija za socijalnu politiku, 17, 1, 2010, 71-88.

8 Jasenka BEGIĆ, Emina BERBIĆ-KOLAR, Lovorka BRAJKOVIĆ, Damir MATANOVIĆ, Marta MILEUSNIĆ, Sara PARAGA, Ivan TOMASIĆ, Ksenija ZEC, Od ideje do promjene: Vodič za pokretanje programa društveno korisnog učenja. Institut za razvoj obrazovanja, Zagreb, 2019. https:// iro.hr/wp-content/uploads/2019/11/Vodi\%C4\%8D-za-pokretanje-programa-dru\%C5\%A1tveno-korisnog-u\%C4\%8Denja.pdf (12. 12. 2020.)

9 Ying-Fang CHEN, Samuel S. PENG, „University students' Internet use and its relationships with academic performance, interpersonal relationships, psychosocial adjustment, and self-evaluation”, Cyberpsychology and Behavior, 11, 4, 2008, 467-469, Jin MAO, "Social Media for Learning: A Mixed Methods Study on High School Students' Technology Affordances and Perspectives", Computers in Human Behavior, 33, 2014., 213-223.

10 Nina BEGIČEVIĆ-REĐEP, Vesna CIGLAR, Valentina KIRINIĆ, Barbara HUNJEK, Silvija LADIĆ FISHER, Ljiljana MAVREK, Draženka SKUPNJAK, Violeta VIDAČEK-HAINŠ, Valentina ŽIHER, Carol JONES, Alson MOORE, Elaine ARNULL, E., Projekt Interkomunity Learning, Comenius Regio Partnership, Vararaždinska županija, Varaždin, 2013. 
VIOLETA VIDAČEK HAINŠ: Društveno odgovorno poslovanje i komuniciranje volontera...

\subsection{Volontiranje i korporativno volontiranje}

Društvena odgovornost je skup obaveza unutar poslovnog sustava koji obuhvaća ekonomske, pravne, etičke i filantropske aktivnosti. ${ }^{11}$ Volontiranje je sastavni dio društvene odgovornosti poduzeća i doprinosi boljim međuljudskim odnosima zaposlenika. ${ }^{12}$ Volontiranje potiče odgovornost studenata volontera ${ }^{13} \mathrm{i}$ omogućava studentima razvoj društvenih vještina kroz pomaganje osobama u potrebi u lokalnoj zajednici. ${ }^{14}$ Volontiranja je „dobrovoljno ulaganje osobnog vremena, truda, znanja i vještina kojima se obavljaju usluge ili aktivnosti za dobrobit druge osobe ili za zajedničku dobrobit (...), bez postojanja uvjeta isplate, novčane nagrade ili potraživanja druge imovinske koristi. ${ }^{15}$ Inicijativu za opće dobro zajednice koja je vidljiva kroz aktivnosti koje planiraju i organiziraju zaposlenici te koje potiče i potvrđuje menadžment poslovne organizacije naziva se korporativno volontiranje. Korporativno volontiranje je „izraz društveno odgovornog poslovanja te podrazumijeva svako poticanje zaposlenika na volontiranje u neprofitnim organizacijama od strane poslodavca. ${ }^{16} \mathrm{Kor}$ porativno volontiranje provodi se u poslovnoj organizaciji koja na formalne i neformalne načine daje potporu zaposlenicima u volontiranju. ${ }^{17}$ Motivacija za volontiranje povezana je s intrinzičnim i ekstrinzičnim čimbenicima. Intrinzični motivi poput vrijednosti učenja i osobnog razvoja izraženiji su od ekstrinzičnih čimbenika poput razvoja karijere i prilagodbe društvu. ${ }^{18}$ Osobe koje

11 Ricky GRIFFIN Management, South Western Mason, OH, USA, 2005.

12 Judy N. MUTHURI, Dirk MATTENWAND, Jeremy MOON „Employee Volunteering and Social Capital: Contributions to Corporate Social Responsibility", British Journal of Management, 20, 2009, 75-89.

13 Chau-kiu CHEUNG, T. Wing LO, Elaine Suk CHING LIU „Relationships between Volunteerism and Social Responsibility in Young Volunteers", Voluntas: International Journal of Voluntary and Nonprofit Organizations26, 3, 2014, 872-889.

14 Michael Scott GARVER, Richard L. DIVINe, Samuel SPRALLS „Segmentation Analysis of the Volunteering Preferences of University Students",Journal of Nonprofit \& Public Sector Marketing, 21, 1, 2009, 1-23.

15 Zakon o volonterstvu (NN, 58/07. i 22/13.) https://www.zakon.hr/z/258/Zakon-o-volonterstvu (23. 9. 2020.)

16 Volonterski centar Zagreb (2016). Korporativno volontiranje: Društveno odgovorno poslovanje koje izgrađuje i povezuje poduzeća, zaposlenike i zajednicu. VCZ, Zagreb. https://www.vcz.hr/ userfiles/vcz_prirucnik_digitalno.pdf (1. 11. 2020.)

17 Jessica B. RODELL, Jonathan E. BOOTH, John W. LYNCH, Kate P. ZIPAY „Corporate Volunteering Climate: Mobilizing Employee Passion for Societal Causes and Inspiring Future Charitable Action", Academic Management Journal, 60, 5, 2017, 1662-1681.

18 Dubravka MILJKOVIĆ, Lana JURČEC, „Povezanost pristupa sreći, motiva za volontiranje i subjektivne dobrobiti volontera“, Napredak: Časopis za interdisciplinarna istraživanja u odgoju i obrazovanju, 56, 1-2, 2015, 115-129. 
volontiraju ugodne su i savjesne osobe, altruistične su, pouzdane i moralne te imaju široke umjetničke interese. ${ }^{19}$

Studenti tijekom studiranja na sveučilištima i visokim učilištima razvijaju akademske i društvene kompetencije. Akademske kompetencije uključuju razvoj kognitivnih, perceptivno motoričkih i jezičnih vještina, dok društvene kompetencije podrazumijevaju pronalaženje ponašanja koja omogućavaju prilagodbu i razvoj društvenih vještina. ${ }^{20}$ Društvene su vještine naučene sposobnosti i strategije koje osnažuju pojedinca i poboljšavaju učinkovitost međuljudskih odnosa. ${ }^{21}$

Studentima su tijekom volontiranja ponuđene mogućnosti razvoja društvenih i interkulturnih kompetencija kroz nastavne i izvannastavne aktivnosti. Interkulturna kompetencija predstavlja skup vještina i spoznaja, odnosno sposobnost interkulturno prikladnog načina djelovanja. ${ }^{22}$ Odgojno-obrazovne ustanove te obrazovne i znanstvene ustanove među kojima su fakultet, akademije i visoka učilišta, ulažu velike napore u proces internacionalizacije visokog obrazovanja. Cilj internacionalizacije je poticanje razvoja kompetencija, komuniciranja studenata u međunarodnom okruženju. Rezultati provedbe projekata učenja o različitim kulturama rezultiraju povećanom razinom samopouzdanja, brige za druge i jačanjem grupne kohezije. Međunarodna mobilnost studenata doprinosi stjecanju ključnih kompetencija važnih za karijerni razvoj i kompetitivnost na tržištu rada. ${ }^{23}$ Broj mobilnosti povećava se tijekom posljednjih godina te raste interes studenata, a posljedično i usvajanje znanja na globalnoj razini (Guruz, 2011). Vrijednosti lokalne zajednice i njena kultura također su važni elementi procesa obrazovanja u multikulturnom okruženju.

19 Marija JUZBAŠIĆ, Tena VUKASOVIC HLUPIĆ, „Osobine ličnosti i motivi za volontiranje“, Psihologijske teme, 24, 2, 2015, 279-304.

20 Frank M. GRESHAM "Social Skills", In: Joseph C. WITT, Stephen N. ELLIOT, Frank M. GRESHAM (eds.) Handbook of Behavior Therapy in Education, Springer, Boston, MA, 1988.

21 Ronald E. RIGGIO, „Assesment of Basic Social Skills", Journal of Personality and Social Psychology, 51, 1986., 649-660.

22 Mitchell R. HAMMER, Milton J. BENNETT, RicharWISEMAN, ,"Measuring Intercultural Sensitivity: The Intercultural Development Inventory", International Journal of Intercultural Relations, 27, 4, 2003, 421-443.

23 Ljerka TOMLJENOVIĆ, „Prikaz projekta KA107 iz programa Erasmus + - partnerska zemlja Bosna i Hercegovina", Zbornik Veleučilišta u Rijeci, 7, 1, 2019., 437-438.

24 Jana NOEL, Developing Multicultural Educators, Weveland Press, Long Grove, IL, USA, 2018. 
Budući da mogućnost pristupa procesu visokog obrazovanja imaju studenti koji dolaze iz različitih okruženja, potrebne su potpore i institucionalne prilagodbe. Istraživanje ${ }^{25}$ uspoređuje politike potpore studentima pripadnicima podzastupljenih skupina u različitim zemljama te daje preporuke za kreiranje politika potpore. Cilj preporuka je kreiranje socijalne politike visokog obrazovanja koja omogućava jednak pristup obrazovanju. U okviru Nacionalnog plana za unaprjeđenje socijalne dimenzije visokog obrazovanja u Republici Hrvatskoj 2019.-2021., podcilja 5. 3., istaknuta je potreba za povećanjem javne financijske potpore za studente koji će tijekom nekog vremena studirati u inozemstvu. Prema podaci$\mathrm{ma}^{27}$ u Hrvatskoj je 2,7\% studenata imalo iskustvo studiranja u inozemstvu. Najčešće su odlazili na studij u Njemačku $(17,4 \%)$ i Sloveniju $(16,5 \%)$, od čega je najveći postotak studenata $(76,2 \%)$ studirao u okviru potpore nekog od EU programa. Studenti koji su bili na međunarodnoj mobilnosti daju pozitivne povratne informacije o iskustvu međunarodne mobilnosti, ističu da su naučili o kulturi druge države kao i da su uočili razlike u odnosu na vlastitu kulturu. Posebno su naglasili kako će im ove kompetencije i znanja koristiti u budućnosti. ${ }^{28}$

\subsection{Kratak opis projekta „Međunarodni istraživački simpozij o interkulturnom učenju“}

Projekt „Međunarodni istraživački simpozij o interkulturnom učenju“ održava se jednom kontinuirano jednom godišnje (2010.-2019.) u Varaždinu ili SAD-u i traje 12 do 14 dana. Cilj projekta je umrežavanje studenata i nastavnika u međuna

25 Jamil SALMI, "Social Dimension Within a Quality Oriented Higher Education System” U: Adrian CURAJ, Ligia DECA, Remus PRICOPIE (Eds.) European Higher Education Area: The Impact of Past and Future Policies, 2019., 141-154. https://link.springer.com/chapter/10.1007/978-3-319-77407-7_10 (1. 10. 2020.)

26 Karmela BARIŠIĆ, Blaženka DIVJAK, Karin DOOLAN, Lelia KIŠ-GLAVAŠ, Ana TECILAZIĆ GORŠIĆ, Sandra SKORUŠEK BLAŽIČKO, Ninoslav ŠĆUKANEC, Aleksandar ŠUŠNJAR, Nacionalni plan za unaprjeđenje socijalne dimenzije visokog obrazovanja u RH 2019. - 2021., Ministarstvo znanosti i obrazovanja, Zagreb, 2018. https://mzo.gov.hr/ (19. 9. 2020.).

27 Ivan RIMAC, Kosta BOVAN, Jelena OGRESTA, „Nacionalno izvješće istraživanja EUROSTUDENT VI za Hrvatsku“, Ministarstvo znanosti i obrazovanja https://mzo.gov.hr 2019. (pristupano ( 25. 9. 2020.)

28 Kristina POKASIĆ, Lovorka ZERGOLLERN-MILETIĆ, Borna NEMET, „Erasmus+ kao instrument poticanja međunarodne suradnje i razvitka kulturne svjesnosti studenata", Croatian Journal of Education, 21, 2, 2019., 539-566. 
rodne istraživačke timove i realizacija volonterskih projekata. Sadržaji obuhvaćaju prezentaciju studentskih istraživanja, suradnju s institucijama lokalne zajednice u području obrazovanja, kulture, sporta te projekte volontiranja u lokalnoj zajednici. Sudjeluju studenti i volonteri Fakulteta organizacije i informatike Varaždin te studenti sa Sveučilišta u SAD-u: University of Central Florida, Orlando, FL, University of Cincinnati, $\mathrm{OH}$, Carlow University Pittsburgh, $P E$, DePaul University Chicago, IL, University of Illinois at Chicago, IL. (Primjeri programa Simpozija: Međunarodni 8. studentski simpozij o interkulturnom učenju 2018. ${ }^{29}$ i Međunarodni 9. studentski simpozij o interkulturnom učenju Fakultet organizacije i informatike Varaždin (2019.). ${ }^{30}$ Tijekom aktivnosti nastoji se potaknuti osjetljivost pojedinaca za potrebe pripadnika socijalno osjetljivih skupina u lokalnoj zajednici, kao što su osobe s invaliditetom, osobe treće životne dobi, obitelji nižeg socioekonomskog statusa i sl. ${ }^{31}$ Slijedom navedenog, ostvarena je inicijalna suradnja s TRIO McNair programom stipendiranja motiviranih studenata prema kriteriju izvrsnosti i pripadnosti podzastupljenim skupinama kao što su studenti nižeg socioekonomskog statusa, prva generacija visoko školovanih u obitelji, pripadnici nacionalnih manjina. ${ }^{32}$

Opći cilj rada je prikazati način provedbe društveno odgovornog poslovanja kroz primjer volontiranja. Specifični ciljevi su: 1. Predstavljanje modela komuniciranja volontera u virtualnom okruženju i u okruženju kontaktne komunikacije licem u lice; 2 . Umrežavanje institucija lokalne zajednice i međunarodnog okruženja kroz projekte volontiranja; 3 . Prikaz mogućnosti diseminacije rezultata provedenih volonterskih aktivnosti prilagođenih stručno znanstvenom i javnom načinu komuniciranja.

29 Međunarodni 8. studenti simpozij o interkulturnom učenju (2018.) Fakultet organizacije i informatike Varaždin https://www.foi.unizg.hr/hr/mobilnost/iskustva-studenata/studenti-foi-ja-usad-u (12. 12. 2020.).

30 Međunarodni 9. studentski simpozij o interkulturnom učenju (2019.). Fakultet organizacije i informatike https://www.foi.unizg.hr/hr/mobilnost/iskustva-studenata/9-medunarodni-studentski-simpozij-o-interkulturalnom-ucenju (12. 12. 2020.).

31 Violeta VIDAČEK-HAINŠ, Michael ALDORANDO JEFFRIES, Blaženka DIVJAK, Renata HORVATEK, (2011) "Student Diversity and Cultural Assimilation: Case Study of the Croatian - USA Student's Exchange Project. The EAN Amsterdam 2011 Conference Book from 20th Conference of European Access Network "Student Diversity in Higher Education: Conflicting Realities"; EAN, Amsterdam, NL, 20.-22. 6. 2011., 40-50.

32 TRIO McNair program University of Central Florida UCF, FL, USA https://mcnair.ucf.edu/index. php (9. 9. 2020.). 


\section{METODOLOGIJA}

U radu su korištene kvantitativne deskriptivne metode i kvalitativne metode analize uspješnosti provedenih aktivnosti volontiranja na osnovu studije slučaja (engl. Case study). Studija slučaja napravljena je na primjeru volontera Centra za volontiranje i humanitarni rad Fakulteta organizacije i informatike (CZVHR FOI). ${ }^{33}$

Prikupljeni su, analizirani i interpretirani 1. primarni statistički podaci o broju i vrsti volonterskih aktivnosti tijekom desetgodišnjeg iskustva u realizaciji Studentskog međunarodnog simpozija o interkulturnom učenju studenata iz Varaždin i SAD-a (2010.-2019.) i 2. sekundarni statistički podaci CZVHR FOI upućeni Ministarstvu za demografiju, obitelj, mlade i socijalnu politiku i realizirani u sklopu akcije „Hrvatska volontira“.

\section{REZULTATI I INTERPRETACIJA REZULTATA}

Aktivnosti volontiranja u sklopu Međunarodnog studentskog istraživačkog simpozija prikazane su kvantitativnim podacima o broju mobilnosti, broju volontera, volonterskih projekata, kontakata s lokalnom zajednicom i ostvarenoj diseminaciji. Aktivnosti Centra za volontiranje i humanitarni rad FOl-ja prikazane su kroz broj volontera i ostvarenih sati volontiranja u manifestaciji „Hrvatska volontira“ te evidenciji prijava broja volontera i volonterskih sati koje je CZVHR FOI uputio Ministarstvu za demografiju, obitelj, mlade i socijalnu politiku.

33 Centar za volontiranje i humanitarni rad Fakulteta organizacije i informatike (CZVHR FOI) https:// www.foi.unizg.hr/hr/fakultet/odjeli/cvhr (05. 09. 2020.). grebu“. https://www.hrvatska.volontira.vcz.hr/hosts/host/143 (2. 9. 2020.). 


\subsection{Volonterske aktivnosti u međunarodnom okruženju: primjer studentskog simpozija o interkulturalnom učenju (2010.-2019.)}

U nastavku su navedeni rezultati međunarodne razmjene studenata koju u razdoblju 2010.-2019. kontinuirano ostvaruju studenti i nastavnici u sklopu Studentskog istraživačkog simpozija o interkulturnom učenju. Tijekom kontinuiranog odvijanja Međunarodnog studentskog simpozija o interkulturnom učenju (2010.-2019.) realizirano je ukupno 85 mobilnosti, od čega $\mathrm{N}=64$ mobilnosti studenata i N=21 mobilnost nastavnika volontera iz Varaždina u SAD i iz SAD-a u Varaždin (grafički prikaz broj 1). Vidljiv je porast broja mobilnosti tijekom godina. Najveći porast mobilnosti uočen je 2018. godine, što ukazuje na sve veću prepoznatljivost i važnost ovog projekta u lokalnom i međunarodnom okruženju. Tako je npr. $\mathrm{N}=6$ studenata uključeno u prvu mobilnost 2010. godine, broj studenata 2019. raste na 10 odnosno 2018. na $\mathrm{N}=13$ studenata uključenih u mobilnost tijekom simpozija.

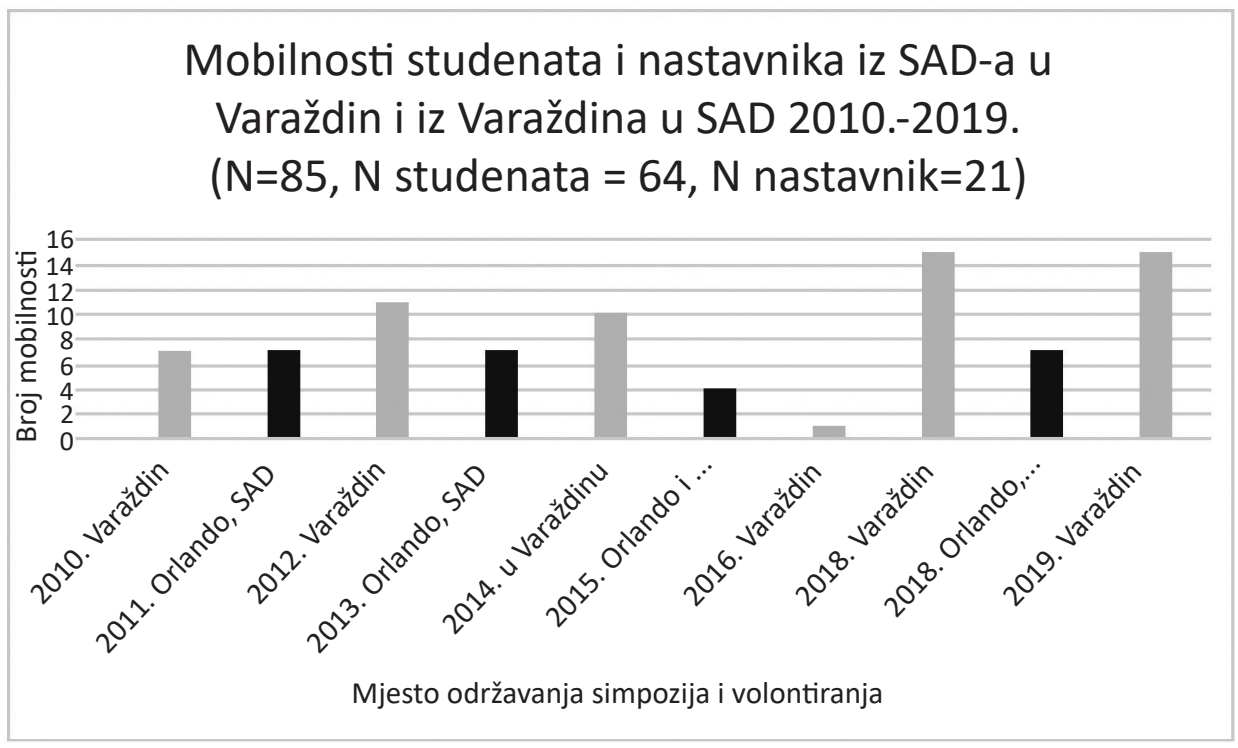

Grafički prikaz br. 1: Mobilnosti studenata i nastavnika iz SAD-a u Varaždin i iz Varaždina u SAD tijekom provedbe aktivnosti Studentskog istraživačkog simpozija o interkulturnom učenju 2010.-2019. ( $N=85$, od čega $\mathrm{N}_{\text {(studenata) }}=64, \mathrm{~N}_{\text {(nastavnika) }}=21$ ) 
VIOLETA VIDAČEK HAINŠ: Društveno odgovorno poslovanje i komuniciranje volontera...

U tablici 1 prikazani su kvantitativni pokazatelji praćenja diseminacije rezultata Simpozija izraženi kroz video uratke, blogove sudionika, objave u medijima, izvješća, publicirane stručne i znanstvene radove, održane prezentacije na konferencijama i stručnim skupovima i potpisane bilateralne međusveučilišne sporazume.

Tablica br. 1: Pregled kvantitativnih pokazatelja praćenja diseminacije provedbe projekta Studentski istraživački simpozij o interkulturnom učenju 2010.2019. ( $N=85)$

\begin{tabular}{|c|c|c|}
\hline Redni broj & Diseminacije & Vrsta diseminacije \\
\hline 1. & 18 & Video uradci studenata web FOI \\
\hline 2. & 16 & Blogovi studenata iz SAD-a \\
\hline 3. & 18 & Blogovi studenata iz Varaždina \\
\hline 4. & 52 & $\begin{array}{l}\text { Objave portali, tisak (Varaždinske vijesti, Regio- } \\
\text { nalni tjednik, STAK...) }\end{array}$ \\
\hline 5. & 5 & Intervjui VTV \\
\hline 6. & 61 & $\begin{array}{l}\text { Prezentacije istraživanja studenata i nastavnika } \\
\text { na Simpoziju u Varaždinu }\end{array}$ \\
\hline 7. & 24 & $\begin{array}{l}\text { Prezentacije istraživanja hrvatskih studenata i } \\
\text { nastavnika na Simpoziju u SAD-u }\end{array}$ \\
\hline 8. & 25 & $\begin{array}{l}\text { Prezentacije istraživačkih radova studenata iz } \\
\text { SAD-a na Studentskoj sekciji međunarodne kon- } \\
\text { ferencije CECIIS u Varaždinu }\end{array}$ \\
\hline 9. & 6 & $\begin{array}{l}\text { Objavljeni studentski radovi u zbornicima konfe- } \\
\text { rencija u Hrvatskoj i SAD-u }\end{array}$ \\
\hline 10. & 16 & $\begin{array}{l}\text { Radovi pratitelja prezentirani na međunarod- } \\
\text { nim konferencijama }\end{array}$ \\
\hline 11. & 25 & Izvješća (FV, SZ, SC, Sveučilište...) \\
\hline 12. & 3 & $\begin{array}{l}\text { Bilateralni međusveučilišni ugovori (2013. i } \\
\text { 2018. })^{35} \mathrm{~s} \text { University of Cincinnati, } \mathrm{OH}^{36} \text { u De Paul } \\
\text { University Chicago, IL-produžetak 2018. ) }\end{array}$ \\
\hline
\end{tabular}

35 International Strategic Partnership, University of Cincinnati, $\mathrm{OH}$, USA https://www.uc.edu/about/international/about/strategic-partnerships.html (10. 10. 2020.)

36 Sveučilište u Zagrebu, Baze suradnje i sporazuma http://www.unizg.hr/suradnja/medunarodna-suradnja/partnerstva/bilateralna-i-multilateralna-suradnja/ (12. 12. 2020.). 
Indirektni kvalitativni pokazatelji su broj pozitivno recenziranih, prezentiranih i/ili objavljenih radova na međunarodnim konferencijama ( $\mathrm{N}=16$ radova pratitelja u SAD-u , Hong Kongu, Hrvatskoj i Albaniji i 6 radova studenata objavljenih na međunarodnim konferencijama u Hrvatskoj i SAD.-u). Diseminaciji rezultata pridonose i objavljeni blogovi s iskustvima studenata koji populariziraju suradnju fakulteta s institucijama lokalne zajednice $(\mathrm{N}=34)$, objave na portalima i u tisku ( $N=52$, Regionalni tjednik, Varaždinske vijesti, STAK...) uz $\mathrm{N}=5$ održanih intervjua sa sudionicima simpozija (Varaždinska televizija). Dio diseminacijskih materijala sadrži elemente intrinzičnih čimbenika motivacije za volontiranje kao što je osobni razvoj i pomoć osobama u potrebi, u skladu s rezultatima. ${ }^{37}$ Tijekom provedbe simpozija poseban naglasak stavljen je na volontiranje i suradnju s institucijama lokalne zajednice u Varaždinu i okolici te u SAD-u. Volonterske aktivnosti proveli su studenti i nastavnici volonteri u okviru Centra za volontiranje i humanitarni rad Fakulteta organizacije i informatike Varaždin (CZVHR FOI). Volonterske aktivnosti usmjerene su na podizanje svijesti studenata i nastavnika o potrebi za pružanjem potpore i pomoći slabije zastupljenim i ranjivim skupinama (osobe $s$ invaliditetom, slabijeg socioekonomskog statusa, nižeg stupnja obrazovanja...). Ukupan broj volonterskih projekata i kontakata ostvarenih s institucijama lokalne zajednice u Varaždinu i široj regiji prikazan je na grafičkom prikazu broj 2.

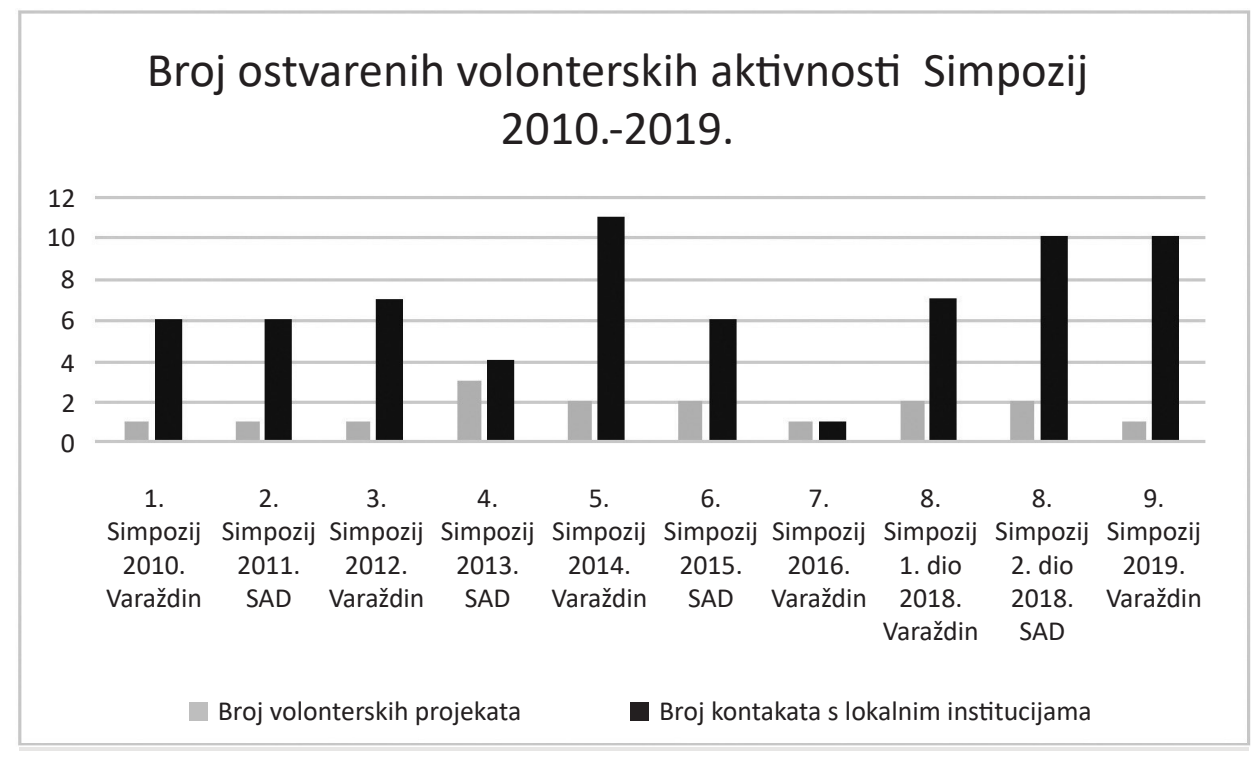

Grafički prikaz br. 2: Broj ostvarenih volonterskih aktivnosti tijekom provedbe Studentskog istraživačkog simpozija o interkulturnom učenju 2010.-2019.

37 Dubravka MILJKOVIĆ, Lana JURČEC, „Povezanost pristupa sreći, motiva za volontiranje i subjektiv- 
U sklopu dosadašnjih Simpozija 2010. - 2019. realizirano je 16 volonterskih projekata i ostvareno 68 kontakata s udrugama i organizacijama koje skrbe o osobama na granici socijalne isključenosti u Varaždinu i okolici (grafički prikaz br. 2). U Varaždinu i okolici provedeni su sljedeći projekti volontiranja: Sportske igre za osobe s invaliditetom (Varaždin, 2010.), volontiranje na poljoprivrednom dobru OŠ Petrijanec (Petrijanec, 2014.), aktivnosti suradnje s DVD Beretinec (2014.), Socijalna samoposluga (2016.-2018.), Knit a Square (2018), Humana Nova Čakovec (2019.). U SAD-u su ostvareni ovi volonterski projekti: volontiranje na poljoprivrednom fakultetskom dobru UCF Orlando, FL (2011.), priprema hrane za beskućnike na sajmu volontiranja UCF, FL (2013.), ekološka akcija čišćenja prilaza McNair UCF, FL i inkluzija osoba s invaliditetom Center on Capacity Building for Minorities with Disabilities Research, University of Illinois at Chicago, IL (2015.), inkluzija osoba s invaliditetom - Center on Capacity Building for Minorities with Disabilities Research, University of Illinois at Chicago, IL i AlValor Chicago, IL Centar za rehabilitaciju osoba s kognitivnim teškoćama u suradnji University of Illinois at Chicago (2015). Na grafičkom prikazu broj 2 prikazan je broj ostvarenih kontakata ili posjeta institucijama lokalne zajednice u Varaždinu i okolici ( $N=68)$. Ostvareni su sljedeći kontakti i posjete institucijama lokalne zajednice u Republici Hrvatskoj u samom gradu (Varaždinska županija, Grad Varaždin, Atletski klub Sloboda Varaždin, Utočište Sv. Nikola Varaždin, I. OŠ Varaždin, V. OŠ Varaždin, VI. OŠ Varaždin, Dječji vrtić „Varaždin“, Muzej grada Varaždina, Turistička zajednica grada Varaždina, Centar tradicijskih kultura Varaždin, Tehnološki park Varaždin, Varaždinska udruga mladih V.U.K., OŠ Petrijanec, DVD Beretinec, KUD Beretinec, NK Črešnjevo, TTS Varaždin i izvan Varaždina (Turistička zajednica Grada Zagreba, Muzej Trakošćan, Muzej lepoglavske čipke Lepoglava, Muzej krapinskih neandertalaca, Life Class Terme Sv. Martin, Humana Nova Čakovec). Osim toga, studenti, nastavnici i volonteri realizirali su kontakte i s institucijama nacionalne i međunarodne razine koje djeluju u Republici Hrvatskoj (Hrvatski paraolimpijski odbor, Veleposlanstvo SAD-a u Zagrebu, mjesta pod zaštitom UNESCO-a: NP Plitvička jezera, Dubrovnik, Split, Trogir, Zadar, Sveučilište u Zadru - Ured za međunarodnu suradnju, Rektorat Sveučilišta u Zagrebu, Ured za međunarodnu suradnju Sveučilišta u Zagrebu, Institut Ivo Pilar Zagreb...).

Umrežavanje i kontakti realizirani su i u SAD-u na sljedećim Fakultetima i Sveučilištima: University of Central Florida, Orlando, FL, University of Cincinnati, $\mathrm{OH}$, Carlow University Pittsburgh, PE, DePaul University Chicago, IL, University of Illinois at Chicago, IL, Carlow University, PA, University of North Florida Jacksonville, FL. Dodatno su ostvareni kontakti i posjete institucijama koje se bave kulturom, znanošću $i$ istraživačkom djelatnošću kao npr. Florida Interactive Entertainment Academy

ne dobrobitivolontera", Napredak:Časopis za interdisciplinarna istraživanja uodgoju iobrazovanju, 56, 1-2, 2015, 115-129. 
FIEA, St. Augustine FL, NASA Kenedy Space Centre, Universal studio Orlando, Wicked Playbill Broadway Musical Orlando, The Art Museum of Chicago, Science Museum Chicago, Field Museum Chicago, Generalni konzulat RH Chicago, Taft Museum of Art, Cincinnati, $\mathrm{OH}$...)

Zanimljiv podatak je da se prilikom otvaranja mrežnih stranica TRIO McNair programa stipendiranja studenata Sveučilišta Centralna Florida iz Orlanda ${ }^{38}$ prikazuju fotografije Varaždina i Hrvatske. Na istim mrežnim strancima postoji i direktna poveznica na mrežnu kameru koja prikazuje glavni gradski Trg kralja Tomislava Varaždin. Ova informacije na stranicama Sveučilišta Centrala Florida ujedno je i promidžba grada Varaždina u okruženju institucije visokog obrazovanja u SAD-u.

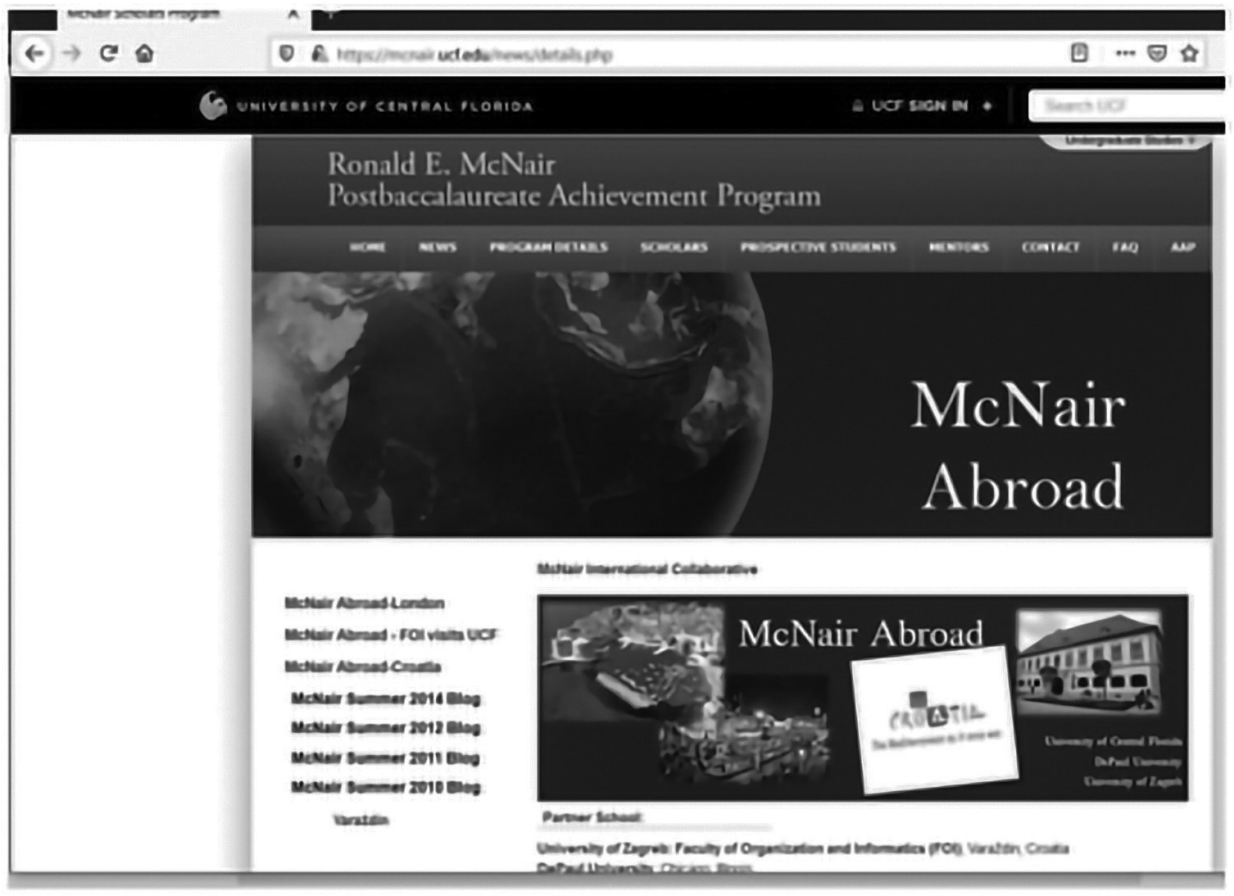

Slika 3: Informacije o Varaždinu i Hrvatskoj na mrežnim stranicama University of Central Florida, Ronald McNair Postbaccalaureate Achievement Program, FL, USA https://mcnair.ucf.edu/news/details.php (12. 12. 2020.)

38 TRIO McNair program University of Central Florida UCF, FL, USA https://mcnair.ucf.edu/index. php (9. 9. 2020.). 
VIOLETA VIDAČEK HAINŠ: Društveno odgovorno poslovanje i komuniciranje volontera...

Navedene volonterske aktivnosti i suradnja s institucijama lokalne, regionalne i međunarodne zajednice doprinosi promidžbi kvalitete vertikale obrazovanja hrvatskih odgojno obrazovnih i znanstvenih institucija u međunarodnom okruženju.

\subsection{Dodatni kvantitativni pokazatelji aktivnosti volontera: ukupan broj volontera i broj ostvarenih volonterskih sati}

Ukupni kvantitativni pokazatelji provedenih volonterskih aktivnosti prikazani su u nastavku rada. Prikupljeni su na nacionalnoj razini i evidentiraju se u sklopu podataka Ministarstva za demografiju, obitelj, mlade i socijalnu politiku. Temeljem članka 33. Zakona o volonterstvu (NN 58/07 i 22/13) i Pravilnika o sadržaju izvješća o obavljenim uslugama ili aktivnostima organizatora volontiranja (NN 009/2018), Centar za volontiranje i humanitarni rad FOI / CZVHR FOI jednom godišnje podnosi Ministarstvu za demografiju, obitelj, mlade i socijalnu politiku izvješće o realiziranom broju volonterskih sadi i ukupnom broju volontera.

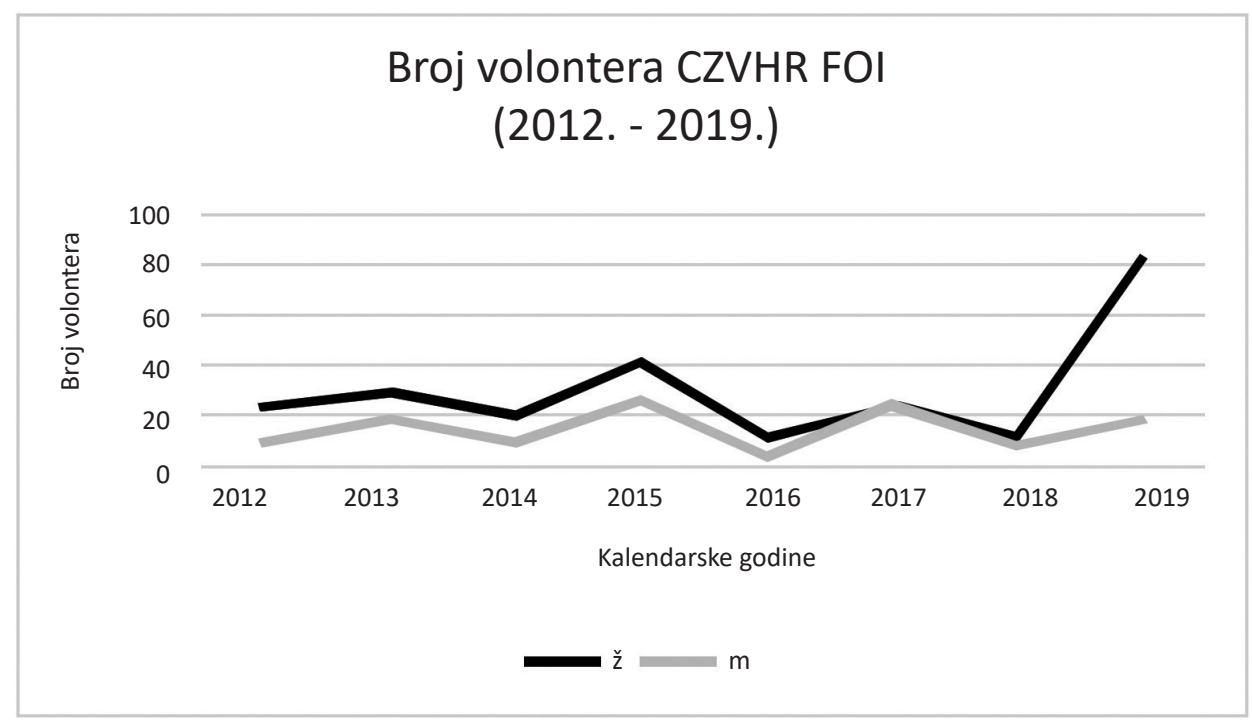

Grafički prikaz br. 3: Broj volontera koji su sudjelovali u projektima volontiranja prema godišnjim izvješćima o obavljenim uslugama ili aktivnostima organizatora volontiranja upućenim Ministarstva za demografiju, obitelj, mlade i socijalnu politiku 
Na grafičkom prikazu 3 vidljiv je porast broja volontera u razdoblju u kojem su se počeli prikupljati i slati podatci Ministarstvu. Tako je npr. 2012. godine u organizaciji CZVHR FOI volontiralo 33 volontera, dok se taj broj povećao na 100 tijekom 2019. godine. Ukupni broj studenata na Fakultetu iznosi godišnje oko 2 500 , što znači da je 2019. postotak studenata koji volontiraju bio oko 4,00 \%. Povećanje broja volontera može se interpretirati u vidu podizanje svijesti volontera za potrebe lokalne zajednice, promidžbe volontiranja i uvođenja izbornog volontiranja u sklopu kurikuluma predmeta Socijalno poduzetništvo na preddiplomskom studiju Ekonomike poduzetništva. Temeljem istog grafičkog prikaza (broj $3)$, vidljiv je veći postotak volonterki (67.49\%) u odnosu na postotak volontera $(32,51 \%)$. Spolne razlike su statistički značajne $\left(x^{2}=26,52, p<0.05\right.$., $\left.d^{\prime}=15\right)$.

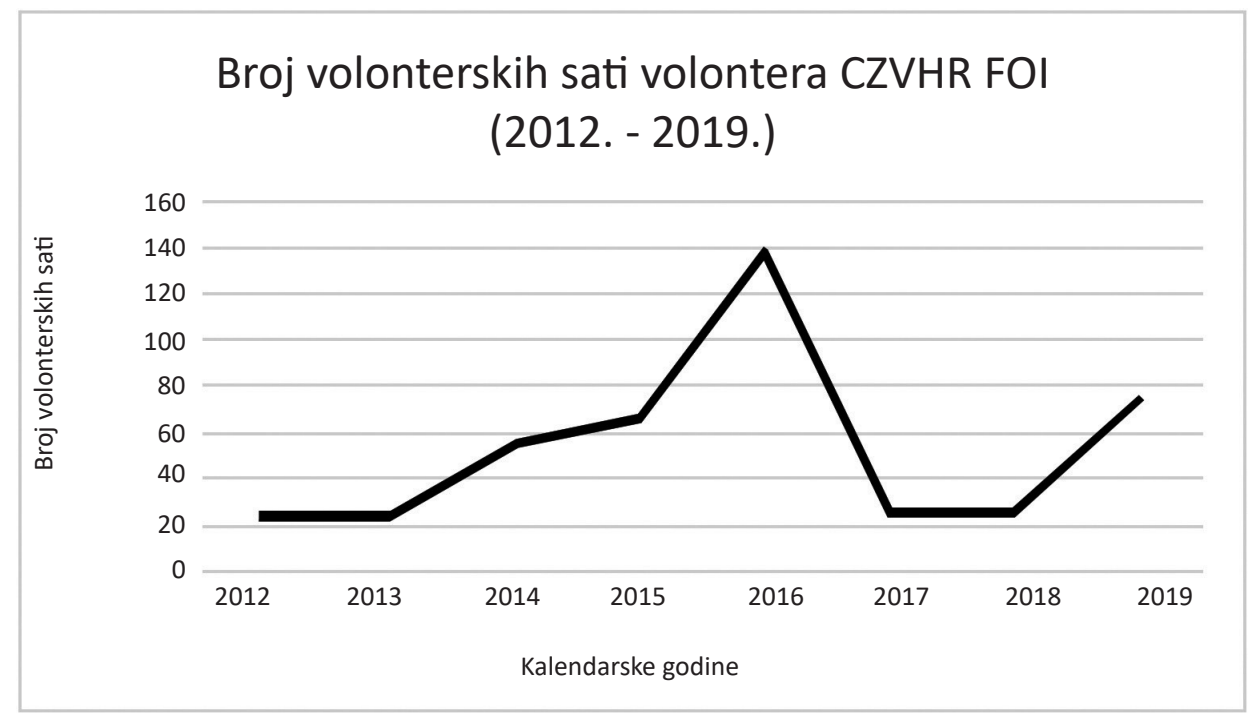

Grafički prikaz br. 4: Broj realiziranih volonterskih sati prema godišnjim izvješćima o obavljenim uslugama ili aktivnostima organizatora volontiranja upućenim Ministarstva za demografiju, obitelj, mlade i socijalnu politiku

Temeljem rezultata prikazanih na grafičkom prikazu broj 4, vidljivo je da se 2012. - 2019. postepeno povećavao broj realiziranih volonterskih sati (od 240 sati 2012. do 1377 realiziranih volonterskih sati tijekom 2016. godine). Nakon manje stagnacije 2017. i 2018. godine, uočljiv je ponovni rast tijekom 2019. godine (740 volonterskih sati). 
Ovom ponovnom rastu vjerojatno doprinosi bolje informiranje, edukacija i uvođenje predmeta na preddiplomskom studiju koji uključuje volontiranje kao izbornu aktivnost. Podaci u Nacrtu prijedloga nacionalnog programa za razvoj volonterstva za razdoblje od 2020. do 2024. godine/ e savjetovanje ${ }^{39}$ pokazuju ukupni porast broja volontera i volonterskih sati u Republici Hrvatskoj. Tako je tijekom 2010. godine u Republici Hrvatskoj djelovalo 206 organizatora volontiranja, a taj se broj popeo na 1502 u 2019., odnosno povećao se 7 puta. Nadalje, ukupan broj sati volontiranja je 2019. godine u odnosu na 2010. porastao je 4 puta, a broj volontera se tijekom ovog razdoblja povećao skoro 5 puta. Udruge organiziraju preko $80 \%$ aktivnosti volontiranja, a ustanove među kojima su i obrazovne institucije oko $10 \%$. Ostali organizatori volontiranja su druge neprofitne pravne osobe, jedinice lokalne uprave i samouprave, državna tijela i ostale organizacije.

\subsection{Dodatni kvantitativni pokazatelji aktivnosti volontera: sudjelovanje u nacionalnoj manifestaciji „Hrvatska volontira“}

Manifestacije koje populariziraju volontiranje dodatno povezuju institucije visokog obrazovanja i institucije lokalne zajednice koje pomažu osobama u potrebi. Jedna od njih je i nacionalna manifestacija „Hrvatska volontira“. ${ }^{40} \mathrm{Cilj}$ ove nacionalne manifestacije je promidžba volontiranja, povećanje osjetljivosti za potrebe lokalne zajednice i pružanje prilike za umrežavanje. Tako je na primjer tijekom 2018. godine u sklopu akcije „Hrvatska volontira“, 157 organizatora u 66 gradova i općina s 3747 volontera provelo 227 volonterki aktivnosti i pri tome realiziralo 14510 volonterki sati. Godinu dana ranije (2017.), 181 organizator volontiranja je u 70 gradova i općina s 4218 volontera, ostvario 22227 volonterskih sati (Hrvatska volontira 2017.). ${ }^{41} \mathrm{U}$ realizaciji aktivnosti volontiranja sudjelovao je i CZVHR FOI. Projekti CZVHR FOI realizirani u sklopu akcije Hrvatska

39 Ministarstvo za demografiju, obitelj, mlade i socijalnu politiku - Nacrt prijedloga nacionalnog programa za razvoj volonterstva za razdoblje od 2020. do 2024. godine - e savjetovanje https:// esavjetovanja.gov.hr/Econ/MainScreen?Entityld=14091 (78-8-2020.).

https://www.hrvatska.volontira.vcz.hr/assets/HV_izvje\%c5\%a1taj_2018_fin_full.pdf(5.9. 2020.).

${ }^{41}$ Izvještaj Hrvatska volontira „Možemo biti jači“, Hrvatska volontira 2017. https://www.vcz.hr/ userfiles/HR_Volontira17_IZVJESTAJ.pdf (5. 9. 2020.).

Hrvatska volontira: Volonterske aktivnosti Fakulteta organizacije i informatike Sveučilišta u Zagrebu“. https://www.hrvatska.volontira.vcz.hr/hosts/host/143 (2. 9. 2020.). 
volontira objavljeni su na mrežnim stranicama navedene manifestacije (Hrvatska volontira - Volonterske aktivnosti Fakulteta organizacije i informatike Sveučilišta u Zagrebu. ${ }^{42}$

Tablica broj 2: Ostvareni sati volontiranja i sudjelovanje volontera u aktivnostima Hrvatska volontira 2015.-2019. (prikaz autorice prema objavljenim podacima Hrvatska volontira) $)^{43}$

\begin{tabular}{|c|c|c|c|c|c|}
\hline R. br. & Godina & $\begin{array}{l}\text { Naziv volonter- } \\
\text { ske akcije CZVHR } \\
\text { FOI u sklopu } \\
\text { manifestacije } \\
\text { "Hrvatska volon- } \\
\text { tira“ }\end{array}$ & Ostvarena suradnja s & $\begin{array}{l}\text { Broj } \\
\text { volon- } \\
\text { tera }\end{array}$ & $\begin{array}{c}\text { Broj volonterskih } \\
\text { sati }\end{array}$ \\
\hline 1. & 2015. & $\begin{array}{l}\text { Atletskom pr- } \\
\text { venstvu Hrvat- } \\
\text { ske za osobe s } \\
\text { invaliditetom } \\
\text { Varaždin }\end{array}$ & $\begin{array}{l}\text { Hrvatski paraolim- } \\
\text { pijski odbor, AK } \\
\text { Sloboda Varaždin }\end{array}$ & 9 & 72 \\
\hline 2. & 2016. & $\begin{array}{l}\text { Upoznajmo } \\
\text { osobe treće } \\
\text { životne dobi s } \\
\text { mogućnostima } \\
\text { komunikacije } \\
\text { putem Interneta }\end{array}$ & $\begin{array}{c}\text { Dom za starije i } \\
\text { nemoćne osobe } \\
\text { Varaždin }\end{array}$ & 38 & 117 \\
\hline 3. & 2017. & $\begin{array}{l}\text { Čišćenje i uređe- } \\
\text { nje okoliša }\end{array}$ & - & 7 & 20 \\
\hline 4. & 2018. & $\begin{array}{c}\text { Knit-a-Square za } \\
\text { djecu u Africi }\end{array}$ & $\begin{array}{c}\text { Knit-a-Square Cro- } \\
\text { atia }\end{array}$ & 6 & 27 \\
\hline 5. & 2019. & $\begin{array}{c}\text { Informatička ra- } \\
\text { dionica za osobe } \\
\text { treće životne } \\
\text { dobi }\end{array}$ & $\begin{array}{c}\text { Dom za starije i } \\
\text { nemoćne osobe } \\
\text { Varaždin }\end{array}$ & 7 & 11 \\
\hline \multicolumn{4}{|c|}{ Ukupno } & 67 & 247 \\
\hline
\end{tabular}

42 Hrvatska volontira: Volonterske aktivnosti Fakulteta organizacije i informatike Sveučilišta u Zagrebu“. https://www.hrvatska.volontira.vcz.hr/hosts/host/143 (2. 9. 2020.).

43 Isto. 
Temeljem uvida u tablicu 2 vidljiva je povezanost CZVHR FOI s institucijama lokalne, nacionalne i međunarodne razine, pri čemu je 67 volontera ostvarilo 247 sati volontiranja. Ovakve aktivnosti omogućavaju studentima volonterima bolji uvid u potrebe osoba na granici socijalne isključenosti, otvaraju mogućnosti za daljnje umrežavanje i stjecanje kompetencija komuniciranja u domaćem i međunarodnom okruženju.

\subsection{Analiza dodatnih kvalitativnih pokazatelja aktivnosti volontiranja}

Analiza kvalitete volonterskih aktivnosti provodi se kontinuiranom evaluacijom temeljem primjene inicijalnog i završnog upitnika namijenjenog volonterima, korisnicima volontiranja i organizatorima volontiranja. Osigurava se edukacija volontera iz područja primjene Zakona o volonterstvu, Etičkog kodeksa volontera i komunikacijskih vještina volontera, kao i specifičnih znanja potrebnih za pojedina područja volontiranja (npr. rad s djecom, starijim i nemoćnim, osobama s invaliditetom i sl.). Aktivnosti se provode u skladu s odredbama Zakona o volonterstvu. ${ }^{44}$

Aktivnosti volontera u Varaždinskoj županiji realiziraju se u okviru mnogobrojnih volonterskih udruga i organizacija, između ostalog u organizaciji Gradskog društva Crvenog križa Varaždinske županije, ${ }^{45}$ donedavno i u okviru Udruge Franjo Košćec, ${ }^{46}$ Udruge za podršku žrtvama i svjedocima ${ }^{47}$ itd. Volonterkama i volonterima CZVHR FOI je u periodu 2013.-2019. dodijeljeno 27 nagrada za volontiranje, među kojima su Državna nagrada za volontiranje, ${ }^{48}$ tri nagrade Grada Varaždina „Naj volonter", jedna Nagradu Rotary cluba Varaždin, sedam volontera je dobilo Rektorovu nagradu i 15 Nagradu dekana (Odluka o dodjeli Državne nagrade za volontiranje u 2013. godini.

${ }_{44}$ Zakon o volonterstvu (NN, 58/07. i 22/13.) https://www.zakon.hr/z/258/Zakon-o-volonterstvu (23. 9. 2020.).

45 Gradsko društvo Crvenog križa Varaždinske županije https://dck-vz.hr/ (12. 12. 2021.).

46 Udruge Franjo Košćec Varaždin http://www.zeleni-telefon.org/?q=hr/taxonomy/term/52 (1. 8. 2020.).

47 Udruge za podršku žrtvama i svjedocima https://pzs.hr/ured-varazdin/ (1. 8. 2020.).

48 Odluka o dodjeli Državne nagrade za volontiranje u 2013. godini NN 144/2013 https://narodne-novine.nn.hr/clanci/sluzbeni/2013_12_144_3085.html (5. 9. 2020.). 


\section{ZAKLJUČAK I MOGUĆNOSTI PRIMJENE REZULTATA}

Izvannastavne aktivnosti sastavnica Sveučilišta potiču umrežavanje institucija u vertikali obrazovanja s institucijama lokalne i međunarodne zajednice. Fakultetski programi volontiranja potiču osjetljivost za potrebe uvođenja društveno odgovornog poslovanja studenata i nastavnika. Volontiranjem studenti razvijaju društvene vještine i vještine komuniciranja u regionalnom i međunarodnom okruženju te usvajaju vrijednosni sustav lokalne zajednice. Motivacija za volontiranje je povezana s intrinzičnim čimbenicima poput osobnog razvoja te ekstrinzičnim čimbenicima poput razvoja karijere.

Aktivnosti volontiranja podižu nivo svijesti o potrebama pojedinaca pripadnika podzastupljenih skupina kao što su osobe s invaliditetom, pripadnici nacionalnih manjina, strani studenti ili državljani, pojedinci nižih primanja, nižeg stupnja obrazovanja i sl. Čimbenici uspješne realizacije volonterskih programa povezani su s edukacijom volontera, kvalitetnim kontinuiranim informiranjem i evaluacijom provedbe volonterskih aktivnosti. Upravljanje projektima volontiranja moguće je uz potporu jedinica lokalne i regionalne uprave i samouprave, studentskih zborova fakulteta i sveučilišta, uprava fakulteta i sveučilišta, ureda za međunarodnu suradnju sastavnica i sveučilišta te institucija lokalne i međunarodne zajednice. Partnerska sveučilišta u međunarodnom okruženju daju mogućnosti za razmjenu iskustava dobre prakse u stručnom, znanstvenome i društvenom kontekstu. Prepoznatljivost kvalitete volontiranja te dodijeljene nagrade i priznanja volonterima predstavljaju dodatnu motivaciju za organizaciju i provedbu volonterskih aktivnosti.

Moguće ograničenje korištene metodologije i interpretacija rezultata predstavlja relativno mali uzorak volontera sudionika Simpozija o interkulturnom učenju (2010.-2019.). Naime, u analizu nisu uključeni ostali međunarodni oblici razmjene studenata i nastavnika koji nisu nužno obuhvaćali volontiranje (npr. Erasmus i slični međunarodni programi razmjene.). Nadalje, rad obuhvaća statističke podatke o broju volontera i volonterskih sati za razdoblje nakon 2012. godine, odnosno od vremena kada se započelo sa sustavnim prikupljanjem podataka na nacionalnoj razini. U radu je veći naglasak je stavljen na kvantitativne, a manji na kvalitativne pokazatelje rezultata.

Podizanje svijesti o postojanju razlika, uvažavanje razlika i pomaganju lokalnoj zajednici temelj su razvoja društvenih vještina studenata volontera. Komuniciranje u međunarodnom okruženju i razvoj društvenih vještina podiže konkurentnost studenata na budućem tržištu rada. Rezultate je moguće primijeniti za kreiranje suradnje u području volontiranja u lokalnoj i međunarodnoj zajednici. 


\section{LITERATURA}

1/ Karmela BARIŠIĆ, Blaženka DIVJAK, Karin DOOLAN, Lelia KIŠ-GLAVAŠ, Ana TECILAZIĆ GORŠIĆ , Sandra SKORUŠEK BLAŽIČKO, Ninoslav ŠĆUKANEC, Aleksandar ŠUŠNJAR, Nacionalni plan za unaprjeđenje socijalne dimenzije visokog obrazovanja u RH 2019. - 2021., Ministarstvo znanosti i obrazovanja, Zagreb, 2018. https://mzo.gov.hr/ (19. 9. 2020.).

2/ Nina BEGIČEVIĆ-REĐEP, Vesna CIGLAR, Valentina KIRINIĆ, Barbara HUNJEK, Silvija LADIĆ FISHER, Ljiljana MAVREK, Draženka SKUPNJAK, Violeta VIDAČEK-HAINŠ, Valentina ŽIHER, Carol JONES, Alison MOORE, Elaine ARNULL, E., Projekt Interkomunity Learning, Comenius Regio Partnership, Varaždinska županija, Varaždin, 2013.

3/ Jasenka BEGIĆ, Emina BERBIĆ-KOLAR, Lovorka BRAJKOVIĆ, Damir MATANOVIĆ, Marta MILEUSNIĆ, Sara PARAGA, Ivan TOMASIĆ, Ksenija ZEC, Od ideje do promjene: Vodič za pokretanje programa društveno korisnog učenja. Institut za razvoj obrazovanja, Zagreb, 2019. https://iro.hr/wp-content/uploads/2019/11/Vodi\%C4\%8D-za-pokretanje-programa-dru\%C5\%A1tveno-korisnog-u\%C4\%8Denja.pdf (12. 12. 2020.).

4/ Catherine BOVILL, "Co-creation in Learning and Teaching: The Case for a Whole-class Approach in Higher Education", Higher Education, 79, 2020., 1023-1037.

5/ Chau-kiu CHEUNG, T. Wing LO, Elaine Suk CHING LIU „Relationships between Volunteerism and Social Responsibility in Young Volunteers", Voluntas: International Journal of Voluntary and Nonprofit Organizations, 26, 3, 2014, 872-889.

6/ Ana Paula CAETANO, Isabel PIMENTA FREIRE, Elsa BISCAIA MACHADO, „Student Voice and Participation in Intercultural Education". Original Journal of New Approaches in Educational Research, 9, 1, 2020., 57-73

7/ Centar za volontiranje i humanitarni rad Fakulteta organizacije i informatike Varaždin https://www.foi.unizg.hr/hr/fakultet/odjeli/cvhr (5. 9. 2020.).

8/ Ying-Fang CHEN, Samuel S. PENG, „University Students' Internet Use and its Relationships with Academic Performance, Interpersonal Relationships, Psychosocial Adjustment, and Self-evaluation", Cyberpsychology and Behavior, 11, 4, 2008, 467-469.

9/ Bojana ĆULUM, Jasminka LEDIĆ, „Učenje zalaganjem u zajednici - integracija visokoškolske nastave i zajednice u procesu obrazovanja društveno odgovornih i aktivnih građana", Revija za socijalnu politiku, 17, 1, 2010, 71-88. 
10/ Michael Scott GARVER, Richard L. DIVINe, Samuel SPRALLS „Segmentation Analysis of the Volunteering Preferences of University Students", Journal of Nonprofit \& Public Sector Marketing, 21, 1, 2009, 1-23.

11/ Kemal GURUZ, „Higher Education and International Student Mobility in the Global Knowledge Economy", SUNY Press, State University of New York Press, Albany, NY, USA, 2011.

12/ Ricky GRIFFIN, Management, South Western Mason, OH, USA, 2005.

13/ International Strategic Partnership, University of Cincinnati, OH, USA https:// www.uc.edu/about/international/about/strategic-partnerships.html (10. 10. 2020.).

14/ Izvještaj Hrvatska volontira „Možemo biti jači“, Hrvatska volontira, 2015. 2019., Volonterske aktivnosti Fakulteta organizacije i informatike Sveučilišta u Zagrebu. https://vcz.hr/userfiles/HV2015_izvjestaj_final.pdf (4. 9. 2020.)

15/ Izvještaj Hrvatska volontira „Možemo biti jači“, Hrvatska volontira 2017. https://https://www.hrvatska.volontira.vcz.hr/assets/HV_izvje\%c5\%a1taj_2018_fin_full.pdf (5. 9. 2020.).

16/ European Commission/Europska komisija (2011). COM/2011/0681 - Communication from the Commission to the European Parliament, the Council, the European Economic and Social Committee and the Committee OF THE Regions. A Renewed EU Strategy 2011-14 for Corporate Social Responsibility Document 52011DC0681 https://eur-lex.europa.eu/legal-content/EN/ TXT/?uri=CELEX:52011DC0681 (12.02. 2021.).

17/ European Community of Consumer Cooperative - Euro Coop (2012). EC Communication - A renewed EU strategy 2011-2014 for Corporate Social Responsibility https://www.eurocoop.coop/news/39-ec-communication-a-renewed-eu-strategy-2011-2014-for-corporate-social-responsibility. html (1. 11. 2020.).

18/ Gradsko društvo Crvenog križa Varaždinske županije https://dck-vz.hr/ (3. 8. 2020.).

19/ Frank M. GRESHAM (1988) Social Skills. In: Joseph C. WITT, Stephen N. ELLIOT, Frank M. GRESHAM (eds.) Handbook of Behavior Therapy, u: Education. Springer, Boston, MA

20/ Mitchell R. HAMMER, Milton J. BENNETT, Richar WISEMAN, „Measuring Intercultural Sensitivity: The Intercultural Development Inventory", International Journal of Intercultural Relations, 27, 4, 2003, 421-443.

21/ "Hrvatska volontira: Volonterske aktivnosti Fakulteta organizacije i informatike Sveučilišta u Zagrebu". https://www.hrvatska.volontira.vcz.hr/hosts/ host/143 (2. 9. 2020.).

22/ Marija JUZBAŠIĆ, Tena VUKASOVIC HLUPIĆ, „Osobine ličnosti i motivi za volontiranje“, Psihologijske teme, 24, 2, 2015, 279-304. 
VIOLETA VIDAČEK HAINŠ: Društveno odgovorno poslovanje i komuniciranje volontera...

23/ Philip KOTLER, Nancy LEE, Društveno odgovorno poslovanje, suvremena teorija i najbolja praksa, M.E.P., Zagreb, 2009.

24/ Jin MAO, „Social Media for Learning: A Mixed Methods Study on High School Students' Technology Affordances and Perspectives", Computers in Human Behavior, 33, 2014., 213-223.

25/ Ministarstva za demografiju, obitelj, mlade i socijalnu politiku: Pravilnik o sadržaju izvješća o obavljenim uslugama ili aktivnostima organizatora volontiranja (NN 009/2018)http://digarhiv.gov.hr/arhiva/263/176997/narodnenovine.nn.hr/clanci/sluzbeni/full/2018_01_9_220.html (10.10.2020.).

26/ Međunarodni 9. studentski simpozij o interkulturnom učenju (2019.). Fakultet organizacije i informatike https://www.foi.unizg.hr/hr/mobilnost/ iskustva-studenata/9-medunarodni-studentski-simpozij-o-interkulturalnom-ucenju (12. 12. 2020.).

27/ Međunarodni 8. studentski simpozij o interkulturnom učenju (2018.) Fakultet organizacije i informatike Varaždin https://www.foi.unizg.hr/hr/mobilnost/iskustva-studenata/studenti-foi-ja-u-sad-u (12. 12. 2020.).

28/ Dubravka MILJKOVIĆ, Lana JURČEC, „Povezanost pristupa sreći, motiva za volontiranje i subjektivne dobrobiti volontera", Napredak: Časopis za interdisciplinarna istraživanja u odgoju i obrazovanju, 56, 1-2, 2015, 115-129.

29/ Ministarstvo za demografiju, obitelj, mlade i socijalnu politiku (2019). Izvješća o obavljenim uslugama ili aktivnostima organizatora volontiranja za 2019. https://mdomsp.gov.hr/istaknute-teme/mladi-i-volonterstvo/volonterstvo-9017/izvjesca-o-obavljenim-uslugama-ili-aktivnostima-organizatora-volontiranja-9038/9038?big=1 (16. 9. 2019.).

30/ Ministarstvo za demografiju, obitelj, mlade i socijalnu politiku - Nacrt prijedloga nacionalnog programa za razvoj volonterstva za razdoblje od 2020. do 2024. godine - e savjetovanje https://esavjetovanja.gov.hr/Econ/MainScreen?Entityld=14091 (15. 9. 2020.).

31/ Jana NOEL, Developing Multicultural Educators. Weveland Press, Long Grove, IL, USA, 2018.

32/ Odluka o dodjeli Državne nagrade za volontiranje u 2013. godini NN 144/2013 https://narodne-novine.nn.hr/clanci/sluzbeni/2013_12_144_3085.html (5. 9. 2020.).

33/ Kristina POKASIĆ, Lovorka ZERGOLLERN-MILETIĆ, Borna NEMET, „Erasmus+ kao instrument poticanja međunarodne suradnje i razvitka kulturne svjesnosti studenata", Croatian Journal of Education, 21, 2, 2019., 539-566. 
34/ Nives MIKELIĆ PRERADOVIĆ, Učenjem do društva znanja: Teorija i praksa društveno korisnog učenja, Zavod za informacijske studije, Filozofski fakultet Sveučilišta u Zagrebu. Zagreb, 2009.

35/ Judy N. MUTHURI, Dirk MATTENWAND, Jeremy MOON „Employee Volunteering and Social Capital: Contributions to Corporate Social Responsibility“, British Journal of Management, 20, 2009, 75-89.

36/ Ronald E. RIGGIO, „Assesment of Basic Social Skills“, Journal of Personality and Social Psychology, 51, 1986., 649-660.

37/ Ivan RIMAC, Kosta BOVAN, Jelena OGRESTA, „Nacionalno izvješće istraživanja EUROSTUDENT VI za Hrvatsku“, Ministarstvo znanosti i obrazovanja https://mzo.gov.hr 2019. (25. 9. 2020.).

38/ Jessica B. RODELL, Jonathan E. BOOTH, John W. LYNCH, Kate P. ZIPAY „Corporate Volunteering Climate: Mobilizing Employee Passion for Societal Causes and Inspiring Future Charitable Action", Academic Management Journal, 60, 5, 2017, 1662-1681.

39/ Jamil SALMI, „Social Dimension Within a Quality Oriented Higher Education System" u: Adrian CURAJ, Ligia DECA, Remus PRICOPIE (Eds.) European Higher Education Area: The Impact of Past and Future Policies, 2019., 141-154. https://link.springer.com/chapter/10.1007/978-3-319-77407-7_10 (1.10.2020.).

40/ Sveučilište u Zagrebu, Baze suradnje i sporazuma http://www.unizg.hr/suradnja/medunarodna-suradnja/partnerstva/bilateralna-i-multilateralna-suradnja/ (12. 12. 2020.).

41/ Ljerka TOMLJENOVIĆ, „Prikaz projekta KA107 iz programa Erasmus+ - partnerska zemlja Bosna i Hercegovina“, Zbornik Veleučilišta u Rijeci, 7, 1, 2019., 437-438.

42/ TRIO McNair program University of Central Florida UCF, FL, USA https:// mcnair.ucf.edu/index.php (9. 9. 2020.).

43/ Udruga Franjo Košćec Varaždin http://www.zeleni-telefon.org/?q=hr/taxonomy/term/52 (1. 8. 2020.).

44/ Udruge za podršku žrtvama i svjedocima https://pzs.hr/ured-varazdin/ (1. 8. 2020.).

45/ University of Central Florida, Ronald McNair Postbaccalaureate Achievement

Program https://mcnair.ucf.edu/news/details.php (12. 10. 2020)

46/ Maja QUIEN, „Društveno odgovorno poslovanje kao konkurentna prednost: analiza ciljeva najuspješnijih tvrtki u Hrvatskoj", Učenje za poduzetništvo, 2, 1, 2012., 303-307. 
VIOLETA VIDAČEK HAINŠ: Društveno odgovorno poslovanje i komuniciranje volontera...

47/ Volonterski centar Zagreb (2016). Korporativno volontiranje: Društveno odgovorno poslovanje koje izgrađuje i povezuje poduzeća, zaposlenike i zajednicu. VCZ, Zagreb. https://www.vcz.hr/userfiles/vcz_prirucnik_digitalno.pdf (1. 11. 2020.).

48/ Volonterski centar Zagreb VCZ (2015). Menadžment volontera: Priručnik zavođenje volontera i volonterskih programa.

https://www.vcz.hr/userfiles/Menadzment\%20volontera-VCZ.pdf (1.8. 202 0$.$) .$

49/ Volonterski centar Split (2019.) Izvješća o obavljenim uslugama ili aktivnostima organizatora volontiranja za 2019. godinu https://www.vcst.info/novosti/635-izvjesce-volontiranje-2019 (1. 8. 2020.)

50/ Ivona VRDOLJAK RAGUŽ, Kate HAZDOVAC „Društveno odgovorno poslovanje i hrvatska gospodarska praksa", Oeconomica Jadertina, 4, 1, 2014., 40-58.

51/ Zakon o volonterstvu (NN, 58/07. i 22/13.) https://www.zakon.hr/z/258/Zakon-o-volonterstvu (23. 9. 2020.).

52/ Violeta VIDAČEK-HAINŠ, Michael ALDORANDO JEFFRIES, Blaženka DIVJAK, Renata HORVATEK, (2011) "Student Diversity and Cultural Assimilation: Case Study of the Croatian - USA Student's Exchange Project. The EAN Amsterdam 2011 Conference Book from 20th Conference of European Access Network "Student Diversity in Higher Education: Conflicting Realities"; EAN, Amsterdam, NL, 20.-22. 6. 2011., 40-50.

\section{SUMMARY}

\section{CORPORATE SOCIAL RESPONSIBILITY AND COMMUNICATION OF VOLUNTEERS IN REAL AND DIGITAL INTERNATIONAL ENVIRONMENT}

The importance of corporate social responsibility is a challenge in both in local and international environments. The article presents networking examples of students and volunteers who participated in international McNair Scholars Exchange Program from the USA and students from Varaždin, Croatia. The goals of international collaboration between students from Varaždin, Chicago, Orlando and Pittsburgh are the development of professional and social competences for communication in an international environment and the raising of awareness for the individual needs of social disadvantaged groups though volunteering projects. This collaboration program includes elements of service learning and volunteering, intercultural learning and scientific professional components. Students are networking in international research teams and preparing projects linked to 
socially disadvantaged groups/students with disabilities, socially/economically disadvantaged backgrounds and the national minority in the process of higher education. Students communicate with direct use of digital technology. The quality evaluation includes quantitative and quality measurement and provides positive feedback. Acquiring knowledge and competences could raise the students' level of competitiveness in future employment.

Key Words: Volunteering; service learning; international collaboration; social disadvantage groups; digital technology. 